\title{
An Optimized Ustilago maydis for Itaconic Acid Production at Maximal Theoretical Yield
}

\author{
Johanna Becker ${ }^{1,+}$, Hamed Hosseinpour Tehrani ${ }^{1,+}$, Philipp Ernst ${ }^{2,+} \mathbb{D}$, Lars Mathias Blank ${ }^{1}$ (D) \\ and Nick Wierckx 2 ,* \\ 1 iAMB - Institute of Applied Microbiology, ABBt-Aachen Biology and Biotechnology, \\ RWTH Aachen University, Worringerweg 1, 52074 Aachen, Germany; johanna.becker@rwth-aachen.de (J.B.); \\ hamed.tehrani@rwth-aachen.de (H.H.T.); lars.blank@rwth-aachen.de (L.M.B.) \\ 2 Institute of Bio- and Geosciences IBG-1: Biotechnology, Forschungszentrum Jülich, 52425 Jülich, Germany; \\ p.ernst@fz-juelich.de \\ * Correspondence: n.wierckx@fz-juelich.de \\ + These authors contributed equally to this manuscript.
}

Citation: Becker, J.; Hosseinpour Tehrani, H.; Ernst, P.; Blank, L.M. Wierckx, N. An Optimized Ustilago maydis for Itaconic Acid Production at Maximal Theoretical Yield. J. Fungi 2021, 7, 20. https://doi.org/10.3390/ jof7010020

Received: 22 November 2020 Accepted: 29 December 2020 Published: 31 December 2020

Publisher's Note: MDPI stays neutral with regard to jurisdictional clai$\mathrm{ms}$ in published maps and institutional affiliations.

Copyright: (C) 2020 by the authors. Licensee MDPI, Basel, Switzerland. This article is an open access article distributed under the terms and conditions of the Creative Commons Attribution (CC BY) license (https:// creativecommons.org/licenses/by/ $4.0 /)$.

\begin{abstract}
Ustilago maydis, a member of the Ustilaginaceae family, is a promising host for the production of several metabolites including itaconic acid. This dicarboxylate has great potential as a bio-based building block in the polymer industry, and is of special interest for pharmaceutical applications. Several itaconate overproducing Ustilago strains have been generated by metabolic and morphology engineering. This yielded stabilized unicellular morphology through fuz7 deletion, reduction of by-product formation through deletion of genes responsible for itaconate oxidation and (glyco)lipid production, and the overexpression of the regulator of the itaconate cluster ria1 and the mitochondrial tricarboxylate transporter encoded by $m t t A$ from Aspergillus terreus. In this study, itaconate production was further optimized by consolidating these different optimizations into one strain. The combined modifications resulted in itaconic acid production at theoretical maximal yield, which was achieved under biotechnologically relevant fed-batch fermentations with continuous feed.
\end{abstract}

Keywords: itaconic acid; U. maydis; metabolic engineering; fungi; yeast

\section{Introduction}

Itaconic acid and its derivatives are found in many application fields, such as the production of paper, paints, and fibers, or in waste water treatment [1-4] providing a stable market for this bio-based chemical. In 2004, the organic acid was classified as one of the top 12 value-added platform chemicals derived from biomass [5]. There is also a strong interest in this molecule in the medical and pharmaceutical sectors, both as an antibacterial compound [6] and as an immunoregulator for the treatment of autoimmune diseases [7] and viral infections including SARS-COV2 [8]. However, its relatively high production cost compared to fossil counterparts like acrylic acid prevents an even more expanded usage range $[9,10]$. Given the already high yield, titer, and rate of the industrially established itaconic acid production process with Aspergillus terreus [11], a qualitative breakthrough in other dimensions of the process window is needed. Non-conventional itaconate-producing yeasts like Ustilago, Candida, or Pseudozyma [12-14] may offer such a breakthrough because of their unicellular morphology as well as their lower sensitivity to medium impurities. It also enables easier handling and scale-up using cheaper raw substrates or even waste streams $[10,15,16]$. However, compared to the filamentous ascomycete A. terreus, the product to substrate yield has to be improved to make $U$. maydis competitive, and this yield also needs to be achievable under industrially relevant conditions [17].

In nature, $U$. maydis is known for its pathogenicity towards maize (Zea mays) causing corn smut disease $[18,19]$. To penetrate and invade maize tissue, $U$. maydis switches from a yeast-like, non-pathogenic to a filamentous, pathogenic cell form [20]. This switch is governed by a complex regulatory pathway which has been investigated in detail (see $[21,22]$ 
for extensive reviews). Although predominantly growing in its yeast form in fermentation processes, $U$. maydis can switch to filamentous growth under stress conditions such as the presence of hydrophobic lipids, low $\mathrm{pH}$, or nitrogen deficiency [23-25]. Filamentous growth causes issues such as high viscosity, reduced oxygen supply, and cell adherence to reactor walls [9]. This can be avoided through the deletion of fuz7, the product of which plays an essential role in regulating pathogenicity and the switch to filamentous growth [23]. This deletion stabilizes the yeast-like morphology of $U$. maydis and $U$. cynodontis without impacting the fitness of the cells under biotechnologically relevant stresses [26,27].

$U$. maydis produces itaconate as one product from a potpourri of metabolites including organic acids such as malate, succinate, and (S)-2-hydroxyparaconate, polyols such as erythritol and mannitol, and different lipidic products including glycolipids and triglycerides [28-33]. It can also metabolize a range of renewable carbon sources, which besides sugar also include glycerol [34], galacturonic acid [35], cellulose [36], xylan [37], and pectin [38]. Although these features make $U$. maydis an attractive candidate for industrial applications $[9,39,40]$, it also poses a drawback because often multiple products are produced simultaneously. This hinders handling and downstream processing, and it also reduces yield on substrate by diverting carbon flux away from the main product [41]. If itaconic acid is to become a bulk chemical, yield is the most relevant production parameter because substrate cost is the decisive price-determining factor. For itaconate production from glucose, the reported maximal theoretical yield is $0.72 \mathrm{~g}_{\text {ITA }} \mathrm{g}_{\mathrm{glu}}{ }^{-1}$, which equals 1 mol $_{\text {ITA }}$ mol $_{\mathrm{glu}^{-1}}{ }^{-1}$. The yield achieved in practice is affected by different factors such as cell density, the metabolic pathway leading up to itaconate (i.e., anaplerosis), bottlenecks in the itaconate biosynthesis pathway itself, side product formation, redox cofactor balancing, and cell maintenance demand $[42,43]$.

In previous studies several knockouts, promotor replacements and overexpression of genes were implemented to increase itaconate production, reduce by-product formation, and stabilize the unicellular morphology $[10,26,41,44,45]$. Those metabolic engineering approaches resulted in several itaconate hyper-producing Ustilago strains with individual modifications. In this study, these modifications are consolidated into one strain, based on the previously engineered $U$. maydis ITA chassis [41]. The resulting strain K14 produces itaconate from glucose at maximum theoretical yield. The catalytic vigor of the strain was demonstrated in fed-batch cultures.

\section{Materials and Methods}

\subsection{Media and Culture Conditions}

All strains used in this work are listed in Table 1. U. maydis strains were grown in YEPS medium containing $10 \mathrm{~g} \mathrm{~L}^{-1}$ yeast extract, $10 \mathrm{~g} \mathrm{~L}^{-1}$ peptone, and $10 \mathrm{~g} \mathrm{~L}^{-1}$ sucrose. As screening medium for production experiments, U. maydis was cultivated in modified Tabuchi medium (MTM) according to Geiser et al. [30]. Besides varying glucose and buffer (2-(N-morpholino) ethanesulfonic acid (MES; $\mathrm{pH}$ adjusted to 6.5 with $\mathrm{NaOH}$ ) or $\mathrm{CaCO}_{3}$ ) concentrations, this medium contained $0.8 \mathrm{~g} \mathrm{~L}^{-1} \mathrm{NH}_{4} \mathrm{Cl}, 0.2 \mathrm{~g} \mathrm{~L}^{-1}$ $\mathrm{MgSO}_{4} \cdot 7 \mathrm{H}_{2} \mathrm{O}, 0.01 \mathrm{~g} \mathrm{~L}^{-1} \mathrm{FeSO}_{4} \cdot 7 \mathrm{H}_{2} \mathrm{O}, 0.5 \mathrm{~g} \mathrm{~L}^{-1} \mathrm{KH}_{2} \mathrm{PO}_{4}, 1 \mathrm{~mL} \mathrm{~L}^{-1}$ vitamin solution, and $1 \mathrm{~mL} \mathrm{~L}^{-1}$ trace element solution. The vitamin solution contained (per liter) $0.05 \mathrm{~g}$ D-biotin, $1 \mathrm{~g}$ D-calcium panthotenate, $1 \mathrm{~g}$ nicotinic acid, $25 \mathrm{~g}$ myo-inositol, $1 \mathrm{~g}$ thiamine hydrochloride, $1 \mathrm{~g}$ pyridoxol hydrochloride, and $0.2 \mathrm{~g}$ para-aminobenzoic acid. The trace element solution contained (per liter) $1.5 \mathrm{~g}$ EDTA, $0.45 \mathrm{~g} \mathrm{ZnSO} \cdot \cdot 7 \mathrm{H}_{2} \mathrm{O}, 0.10 \mathrm{~g} \mathrm{MnCl} \cdot 4 \mathrm{H}_{2} \mathrm{O}$, $0.03 \mathrm{~g} \mathrm{CoCl}_{2} \cdot 6 \mathrm{H}_{2} \mathrm{O}, 0.03 \mathrm{~g} \mathrm{CuSO}_{4} \cdot 5 \mathrm{H}_{2} \mathrm{O}, 0.04 \mathrm{~g} \mathrm{Na}_{2} \mathrm{MoO}_{4} \cdot 2 \mathrm{H}_{2} \mathrm{O}, 0.45 \mathrm{~g} \mathrm{CaCl}_{2} \cdot 2 \mathrm{H}_{2} \mathrm{O}, 0.3 \mathrm{~g}$ $\mathrm{FeSO}_{4} \cdot 7 \mathrm{H}_{2} \mathrm{O}, 0.10 \mathrm{~g} \mathrm{H}_{3} \mathrm{BO}_{3}$, and $0.01 \mathrm{~g} \mathrm{KI}$. When using $\mathrm{CaCO}_{3}$, medium components were added relative to the total volume of solids plus liquid, leading to a higher aqueous concentration of soluble components. Shaking cultures of $U$. maydis were performed in 24-well System Duetz ${ }^{\circledR}$ plates with a filling volume of $1.5 \mathrm{~mL}$ (shaking diameter $=50 \mathrm{~mm}$, $n=300 \mathrm{rpm}, \mathrm{T}=30{ }^{\circ} \mathrm{C}$ and $\Phi=80 \%$ ) [46] or in $500 \mathrm{~mL}$ shaking flasks with a filling volume of $50 \mathrm{~mL}$ (shaking diameter $=25 \mathrm{~mm}, n=200 \mathrm{rpm}, \mathrm{T}=30^{\circ} \mathrm{C}$ and $\Phi=80 \%$ ). When using System Duetz ${ }^{\circledR}$, cultures were inoculated in parallel into multiple plates in order to 
ensure continuous oxygenation by taking a complete plate as sacrificial sample for each sample point.

Table 1. U. maydis MB215 strains used in this study.

\begin{tabular}{|c|c|c|}
\hline Strain Designation & Resistance & Reference \\
\hline U. maydis MB215 & & {$[47]$} \\
\hline U. maydis MB215 $\Delta c y p 3 \Delta P_{\text {ria } 1}:: P_{\text {etef }}$ & & [10] \\
\hline $\begin{array}{c}\text { U. maydis MB215 } \Delta \text { UMAG_05079 } \\
P_{\text {etef }} m t t A\end{array}$ & hyg $^{\mathrm{R}}, \mathrm{cbx}^{\mathrm{R}}$ & {$[48]$} \\
\hline $\begin{array}{l}\text { U. maydis MB215 } \Delta c y p 3 \Delta f u z 7 \Delta P_{\text {rial } 1}: P_{\text {etef }} \\
P_{\text {etef }} m t t A_{-} \text {K14 }\end{array}$ & hyg $^{\mathrm{R}}, \mathrm{cbx} \mathrm{R}^{\mathrm{R}}$ & {$[10]$} \\
\hline $\begin{array}{l}\text { U. maydis MB215 } \Delta \text { cyp3 } \Delta \text { MEL } \Delta \mathrm{UA} \\
\Delta \text { dgat } \Delta P_{\text {ria } 1}: P_{\text {etef }}(=\mathrm{ITA} \text { chassis })\end{array}$ & & {$[41]$} \\
\hline $\begin{array}{c}\text { U. maydis MB215 } \Delta \text { cyp3 } \Delta \text { MEL } \Delta \mathrm{UA} \\
\Delta d \text { gat } \Delta P_{\text {ria } 1}: P_{\text {etef }} \Delta \text { fuz7 }\end{array}$ & & this study \\
\hline $\begin{array}{l}\text { U. maydis MB215 } \Delta \text { cyp3 } \Delta \text { MEL } \Delta \mathrm{UA} \\
\Delta \text { dgat } \Delta P_{\text {ria } 1}:: P_{\text {etef }} \Delta \text { fuz7 } P_{\text {etef }} m t t A \_\mathrm{K} 3\end{array}$ & $\operatorname{cbx} x^{R}$ & this study \\
\hline $\begin{array}{l}\text { U. maydis MB215 } \Delta \text { cyp3 } \Delta \text { MEL } \Delta \mathrm{UA} \\
\Delta \text { dgat } \Delta P_{\text {ria } 1}:: P_{\text {etef }} \Delta \text { fuz7 } P_{\text {etef }} m t t A \_\mathrm{K} 8\end{array}$ & $\mathrm{cbx}^{\mathrm{R}}$ & this study \\
\hline $\begin{array}{l}\text { U. maydis MB215 } \Delta c y p 3 \Delta \text { MEL } \Delta \mathrm{UA} \\
\Delta \text { dgat } \Delta P_{\text {ria } 1}:: P_{\text {etef }} \Delta f u z 7 P_{\text {etef }} m t t A \_\mathrm{K} 9\end{array}$ & $\operatorname{cbx} x^{R}$ & this study \\
\hline $\begin{array}{c}\text { U. maydis MB215 } \Delta \text { cyp } 3 \Delta \text { MEL } \Delta \mathrm{UA} \\
\Delta \text { dgat } \Delta P_{\text {ria } 1}:: P_{\text {etef }} \Delta \text { fuz7 } P_{\text {etef }} m t t A_{-} \text {K10 }\end{array}$ & $\mathrm{cbx}^{\mathrm{R}}$ & this study \\
\hline $\begin{array}{c}\text { U. maydis MB215 } \Delta \text { cyp3 } \Delta \text { MEL } \Delta \mathrm{UA} \\
\Delta \text { dgat } \Delta P_{\text {rial } 1}: P_{\text {etef }} \Delta \text { fuz7 } P_{\text {etef }} m t t A \_\mathrm{K} 14 \\
(=\mathrm{K} 14 \text { strain })\end{array}$ & $\mathrm{cbx}^{\mathrm{R}}$ & this study \\
\hline
\end{tabular}

Pulsed fed-batch fermentations were performed in New Brunswick BioFlo ${ }^{\circledR} 115$ bioreactors (Eppendorf, Germany) as described in [10]. Fed-batch fermentations with continuous feed were performed in a 2.0 L DASGIP ${ }^{\circledR}$ Bioblock bioreactor (Eppendorf, Germany) with a starting volume of $1.0 \mathrm{~L}$. The medium contained $120 \mathrm{~g} \mathrm{~L}^{-1}$ glucose, $0.8 \mathrm{~g} \mathrm{~L}^{-1}$ or $4 \mathrm{~g} \mathrm{~L}^{-1}$ $\mathrm{NH}_{4} \mathrm{Cl}, 0.2 \mathrm{~g} \mathrm{~L}^{-1} \mathrm{MgSO}_{4} \cdot 7 \mathrm{H}_{2} \mathrm{O}, 0.01 \mathrm{~g} \mathrm{~L}^{-1} \mathrm{FeSO}_{4} \cdot 7 \mathrm{H}_{2} \mathrm{O}, 0.5 \mathrm{~g} \mathrm{~L}^{-1} \mathrm{KH}_{2} \mathrm{PO}_{4}, 1 \mathrm{~mL} \mathrm{~L}^{-1}$ vitamin solution as specified above, $1 \mathrm{~mL} \mathrm{~L}^{-1}$ trace element solution as specified above, and $1 \mathrm{~g} \mathrm{~L}^{-1}$ yeast extract. When the glucose concentration reached approximately $50 \mathrm{~g} \mathrm{~L}^{-1}$, a constant feed of a $50 \%$ glucose solution was started. Feeding rates of 0.75 and $2.8 \mathrm{~g} \mathrm{~h}^{-1}$ were estimated from the glucose consumption rates of previous pulsed fed-batch fermentations under similar conditions. During cultivation, the $\mathrm{pH}$ was controlled by automatic addition of $5 \mathrm{M} \mathrm{NaOH}$ and $1 \mathrm{M} \mathrm{HCl}$. $0.5 \mathrm{~mL}$ Antifoam 204 (Sigma Life Science, St. Louis, O, USA) was added manually every $24 \mathrm{~h}$ to avoid foam formation. The dissolved oxygen (DO) was controlled at $30 \%$ by using a cascade mode including stirring $800-1200 \mathrm{rpm}$, air flow 1-2 $\mathrm{L} \mathrm{min}^{-1}$ and the addition of pure oxygen. The $\mathrm{CO}_{2}$ formation was determined with the DASGIP GA4 module, employing infrared (IR) sensors (BlueSens). The cultivations were performed at $30^{\circ} \mathrm{C}$. Bioreactors were inoculated to an optical density measured at a wavelength of $600 \mathrm{~nm}\left(\mathrm{OD}_{600}\right)$ of 0.75 from a $48 \mathrm{~h}$ preculture in $50 \mathrm{~mL}$ MTM.

\subsection{Analytical Methods}

When using $\mathrm{CaCO}_{3}$ as buffer, $1 \mathrm{~mL}$ culture broth was taken for $\mathrm{OD}_{600}$ and highperformance liquid chromatography (HPLC) analysis. The $\mathrm{CaCO}_{3}$ was dissolved 1:1 with $4 \mathrm{M} \mathrm{HCl}$ prior to further measurements as described in Zambanini et al. [49]. Cell densities were measured by determining the absorption at $600 \mathrm{~nm}$ with an Ultrospec 10 Cell Density Meter (Amersham Biosciences, UK). 
For HPLC analysis, all samples were filtered with Rotilabo ${ }^{\circledR}(\mathrm{CA}, 0.2 \mu \mathrm{m}, \varnothing 15 \mathrm{~mm})$ or Acrodisc ${ }^{\circledR}$ (GHP, $0.2 \mu \mathrm{m}, \varnothing 13 \mathrm{~mm}$ ) syringe filters and diluted 1:5 or 1:10 with $5 \mathrm{mM}$ $\mathrm{H}_{2} \mathrm{SO}_{4}$ or deionized water. Products in the supernatant were analyzed using a DIONEX UltiMate 3000 HPLC System (Thermo Scientific, Waltham, Massachusetts, USA) or a Agilent 1260 Infinity HPLC system (Agilent, Waldbronn, Germany) with an ISERA MetabAAC column $300 \times 7.8 \mathrm{~mm}$ column (ISERA, Düren, Germany). As mobile phase, $5 \mathrm{mM}$ $\mathrm{H}_{2} \mathrm{SO}_{4}$ with a constant flow rate of $0.6 \mathrm{~mL} \mathrm{~min}{ }^{-1}$ and a temperature of $40{ }^{\circ} \mathrm{C}$ was used. When using the DIONEX UltiMate 3000 HPLC System, detection was carried out by a DIONEX UltiMate 3000 Variable Wavelength Detector set to $210 \mathrm{~nm}$ and a SHODEX RI101 detector (Showa Denko Europe GmbH, Munich, Germany). When using the Agilent 1260 Infinity HPLC system, detection was undertaken by a diode array detector (DAD) at $210 \mathrm{~nm}$ and a refraction index (RI) detector. Analytes were identified via retention time and ultraviolet (UV)/RI ratio compared to corresponding standards.

All values are the arithmetic mean of at least two biological replicates. For $n=2$, error bars indicate the deviation from the mean and for $\mathrm{n}>2$ error bars indicate the standard error of the mean. Statistical significance was evaluated by $\mathrm{t}$ test (two-tailed distribution, heteroscedastic, $p \leq 0.05$ ).

\subsection{Plasmid Cloning and Strain Engineering}

Plasmids were constructed by Gibson assembly [50] using the NEBuilder ${ }^{\circledR}$ HiFi DNA Assembly Cloning Kit (New England Biolabs (NEB), Ipswich, MA, USA). Primers were ordered as DNA oligonucleotides from Eurofins Genomics (Ebersberg, Germany). As polymerase, Q5 ${ }^{\circledR}$ High-Fidelity DNA Polymerase (NEB) was used. Detailed information about utilized primers and plasmids are listed in Table 2 and Supplemental Table S1. Competent E. coli DH5 $\alpha$ were used for standard cloning and plasmid maintenance according to Sambrook et al. [51]. Plasmids were confirmed by polymerase chain reaction (PCR) or sequencing. Generation of protoplasts and transformation of $U$. maydis were performed according to Brachmann et al. [52]. Genomic DNA of $U$. maydis was isolated according to Hoffman et al. [53]. For the deletion of fuz7, homologous recombination with $1000 \mathrm{bp}$ flanking regions including FRT-sites and a hygromycin resistance cassette were used [54]. Successful integration and deletion was verified by PCR and sequencing. For the overexpression of $m t t A$, the plasmid $P_{\text {etef }}-\mathrm{Cbx}-A T \_m t t A$ was used [48].

Table 2. Plasmids used in this study.

\begin{tabular}{|c|c|c|}
\hline Plasmid & Description & Reference \\
\hline pJET1.2/blunt & Ori ColE1; AmpR & Thermo Scientific, Germany \\
\hline pFLPexpC & $\begin{array}{l}P_{\text {crg1 } 1 \text { promoter; synthetic FLP }} \\
\text { recombinase gene; CbxR; ARS; } \\
\text { AmpR }\end{array}$ & $\begin{array}{l}\text { Prof. M. Feldbrügge, } \\
\text { Heinrich-Heine University } \\
\text { Düsseldorf, Germany }\end{array}$ \\
\hline pUMa1523 & $\begin{array}{l}\text { FRTm1-HygR-FRTm1 cassette; } \\
\text { GentR }\end{array}$ & $\begin{array}{c}\text { Dr. K. Schipper, } \\
\text { Heinrich-Heine University } \\
\text { Düsseldorf, Germany }\end{array}$ \\
\hline $\begin{array}{c}\text { pJET1.2-fuz7 5'-UTR flank } \\
\text {-FRTm1-HygR-FRTm1-fuz7 } \\
\text { 3'-UTR flank }\end{array}$ & $\begin{array}{l}\text { pJET1.2 with 5'- and 3'-UTR } \\
\text { flank of UMAG_01514 as } \\
\text { deletion construct; HygR; FRT } \\
\text { m1 recombination sites }\end{array}$ & this study \\
\hline$P_{\text {etef }}-\mathrm{Cbx}-A T \_m t t A$ & $\begin{array}{c}\text { constitutive } P_{\text {etef }} \text { promoter, } \\
\text { dicodon-optimized version of } \\
\text { A. terreus ATEG_09970 }(m t t A), \\
\text { cbxR, ampR }\end{array}$ & [48] \\
\hline
\end{tabular}

Quantitative PCR was applied to determine the copy number of $m t t A$ integrated into the U. maydis genome using Luna ${ }^{\circledR}$ Universal qPCR Master Mix (NEB, Frankfurt, Germany). Primers were designed using "GenScript Real-Time PCR (TaqMan) Primer Design" tool 
(Gen Script, Piscataway, New Jersey, USA). Primer sequences are given in Table 3. As reference genes, UMAG_02592 and UMAG_03726 were amplified with the primer pairs JB-126/JB-127 and JB-128/JB-129. Primers JB-132/JB-133 specifically bound within the $m t t A$ sequence (Supplemental Table S1). Amplification curves were taken by Bio-Rad CFX ConnectTM Real-Time PCR Detection system and data were analyzed by using Bio-Rad CFX ManagerTM 3.1 software (Bio-Rad Laboratories, Hercules, CA, USA) using the $\Delta \mathrm{Ct}$ method according to Pfaffl [55].

\section{Results and Discussion}

3.1. Prevention of Filamentous Growth by fuz7 Deletion and Its Influence on Itaconate Production

In previous work, itaconate production with Ustilago has been significantly improved. The characterization and upregulation of the itaconate gene cluster $[44,56,57]$ as well as the engineering of the mitochondrial carrier for cis-aconitate [48] has laid the foundation for this improvement. Those achievements were combined with further modifications including the deletion of genes responsible for itaconate oxidation (cyp3) and (glyco)lipid production (MEL, UA, dgat), resulting in the $U$. maydis MB215 ITA chassis ( $\triangle$ cyp3 $\Delta$ MEL $\Delta \mathrm{UA} \Delta d g a t$ $\left.\Delta P_{\text {ria } 1}:: P_{\text {etef }}\right)$ with reduced by-product formation [41]. Filamentous growth was observed for this strain, similar to other engineered $U$. maydis variants [10]. The morphology switch is likely induced by the additional stress imposed by the metabolic engineering itself, and the resulting high itaconate titers and associated low $\mathrm{pH}$. This drawback can be overcome by the deletion of $f u z 7$ (UMAG_01514) [26,27]. The influence of this knockout in the $U$. maydis MB215 ITA chassis was assessed in System Duetz ${ }^{\circledR}$ cultivations in MTM containing $50 \mathrm{~g} \mathrm{~L}^{-1}$ glucose and $100 \mathrm{mM}$ MES (Figure 1). Under these conditions, the $\Delta f u z 7$ strain produced 1.3-fold more itaconate than the reference ITA chassis strain (Figure 1A, Table 3). Full consumption of glucose by both strains resulted in an equivalently improved yield of the $\Delta f u z 7$ strain to $0.45 \pm 0.01 \mathrm{~g}_{\text {ITA }} \mathrm{g}_{\text {glu }}{ }^{-1}$. The overall production rate was increased by $12 \%$ and the maximal rate even by $26 \%$ (Table 3 ).
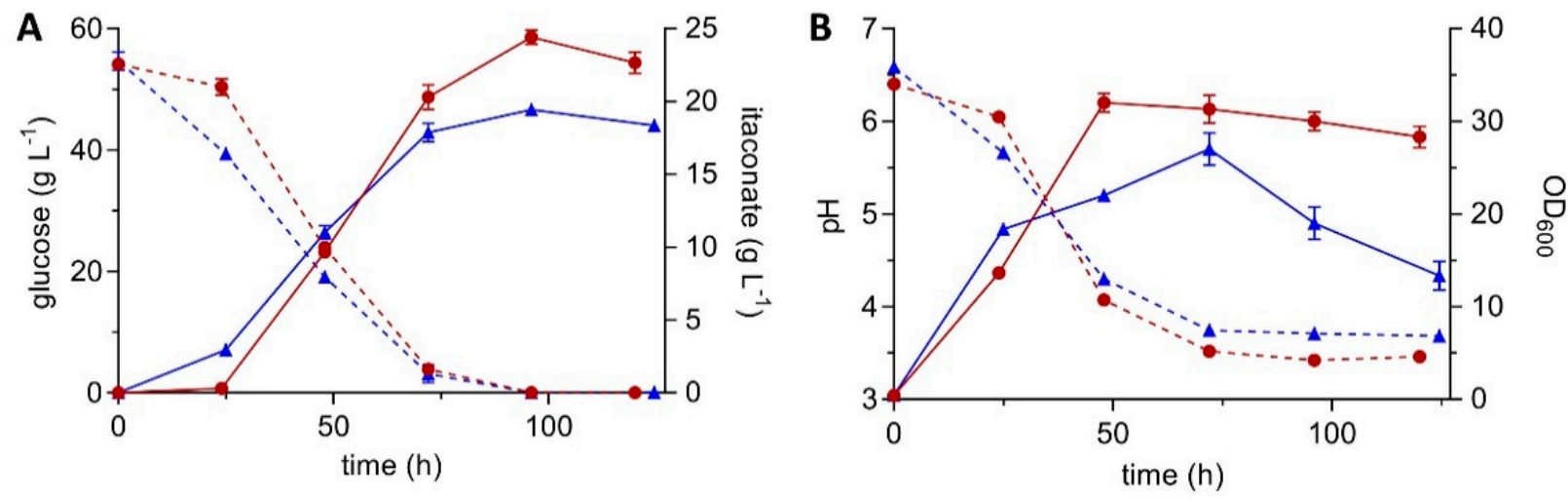

Figure 1. System Duetz ${ }^{\circledR}$ cultivation of morphology-engineered U. maydis MB215 strains in modified Tabuchi medium (MTM) with $50 \mathrm{~g} \mathrm{~L}^{-1}$ glucose and $100 \mathrm{mM}$ (2-(N-morpholino) ethanesulfonic acid (MES), incubated in 24-well plates with a filling volume of $1.5 \mathrm{~mL}$ (shaking diameter $=50 \mathrm{~mm}, n=300 \mathrm{rpm}, \mathrm{T}=30^{\circ} \mathrm{C}$ and $\Phi=80 \%$ ). (A) Concentrations of itaconate (continuous lines) and glucose (dotted lines), (B) optical density measured at a wavelength of $600 \mathrm{~nm}\left(\mathrm{OD}_{600}\right.$, continuous lines) and $\mathrm{pH}$ (dotted lines) of $U$. maydis MB215 $\Delta$ cyp3 $\Delta$ MEL $\Delta \mathrm{UA} \Delta d g a t \Delta P_{\text {ria } 1}:: P_{\text {etef }}(\mathbf{\Delta})$ and the same strain with additional fuz7 deletion $(\bullet)$. Error bars indicate the standard error of the mean $(n=3)$. 

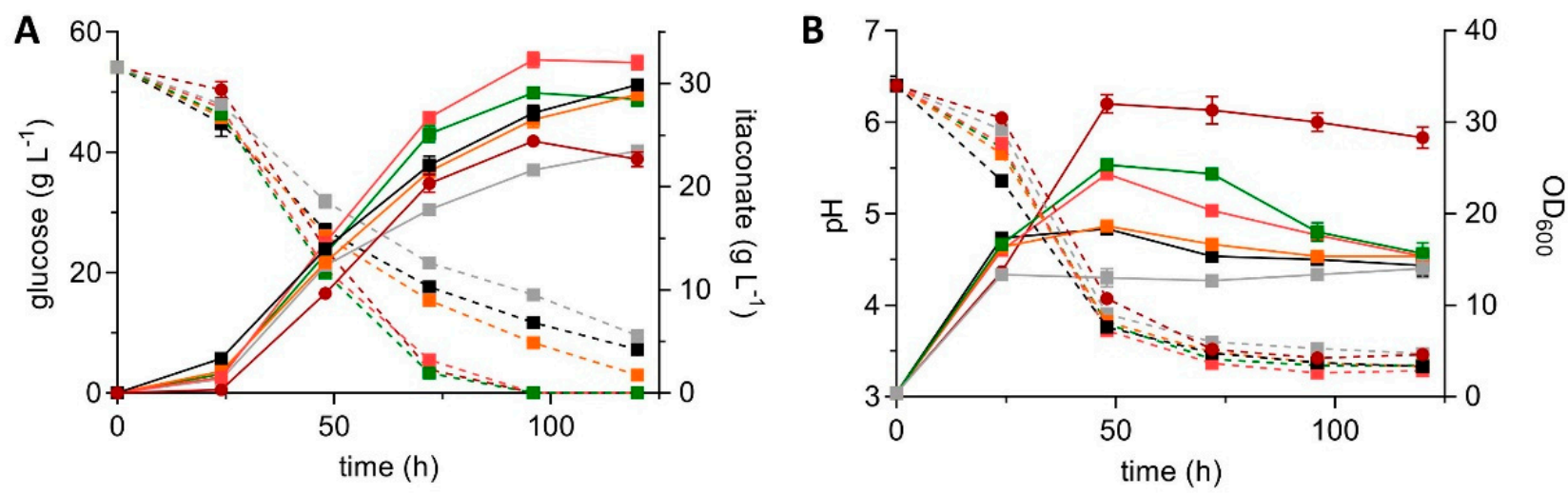

Figure 2. System Duetz ${ }^{\circledR}$ cultivation of $U$. maydis MB215 strains expressing $m t t A$ in MTM with $50 \mathrm{~g} \mathrm{~L}^{-1}$ glucose and $100 \mathrm{mM}$ MES, incubated in 24-well plates with a filling volume of $1.5 \mathrm{~mL}$ (shaking diameter $=50 \mathrm{~mm}, n=300 \mathrm{rpm}, \mathrm{T}=30{ }^{\circ} \mathrm{C}$ and $\Phi=80 \%$ ). Itaconate production (continuous lines) and glucose consumption (dotted lines) (A) are shown, as well as $\mathrm{OD}_{600}$ (continuous lines) and $\mathrm{pH}$ (dotted lines) (B) of $U$. maydis MB215 $\Delta$ cyp3 $\Delta$ MEL $\Delta \mathrm{UA} \Delta d g a t \Delta P_{\text {ria } 1}:: P_{\text {etef }} \Delta$ fuz7 (red) and five $\mathrm{P}_{\text {etef }} m t t A$ transformants named K3 (grey), K8 (green), K9 (orange), K10 (pink), and K14 (black). Error bars indicate the standard error of the mean $(n=3)$.
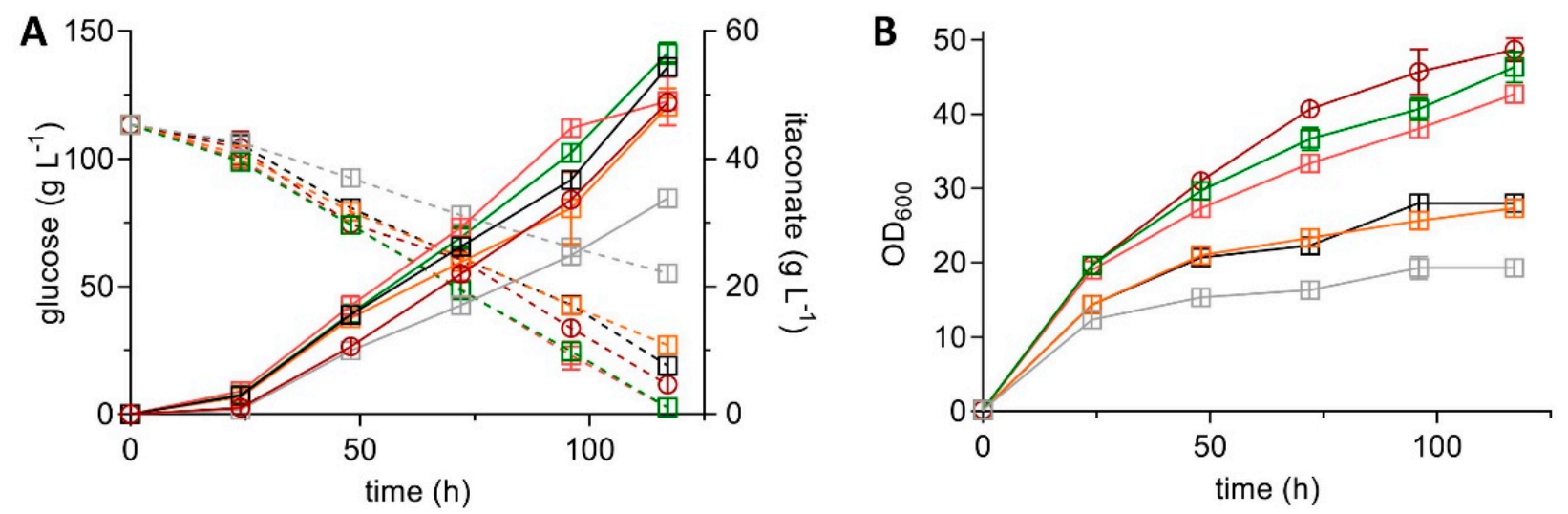

Figure 3. System Duetz ${ }^{\circledR}$ cultivation of six $U$. maydis MB215 mutants in MTM with $100 \mathrm{~g} \mathrm{~L}^{-1}$ glucose and $66 \mathrm{~g} \mathrm{~L}^{-1} \mathrm{CaCO}_{3}$, incubated in 24-well plates with a filling volume of $1.5 \mathrm{~mL}$ (shaking diameter $=50 \mathrm{~mm}, n=300 \mathrm{rpm}, \mathrm{T}=30{ }^{\circ} \mathrm{C}$ and $\Phi=80 \%$ ). Concentrations of itaconate (continuous lines) and glucose (dotted lines) (A) are shown, as well as $\mathrm{OD}_{600}(\mathbf{B})$ of U. maydis MB215 $\Delta$ cyp3 $\Delta$ MEL $\Delta \mathrm{UA} \Delta$ dgat $\Delta P_{\text {ria } 1}: P_{\text {etef }} \Delta f u z 7$ (red) and five $P_{\text {etef }} m t t A$ transformants $U$. maydis MB215 $\Delta c y p 3$ $\Delta$ MEL $\Delta$ UA $\Delta$ dgat $\Delta P_{\text {rial }}:: P_{\text {etef }} \Delta f u z 7 P_{\text {etef }} m t t A, \mathrm{~K} 3$ (grey), K8 (green), K9 (orange), K10 (pink), and K14 (black). Error bars indicate the standard error of the mean $(n=3)$.

These results clearly illustrate the benefit of preventing filamentous growth. In these deeply engineered strains of $U$. maydis, cells start to adhere to the walls of the culture plates during the production phase, likely as a result of the combined stress of ammonium limitation, low $\mathrm{pH}$ and increasing product concentrations [23-25]. This adhesion has been described in detail in Hosseinpour-Tehrani et al. [10]. The resulting cell accumulations likely encounter oxygen, buffer, and nutrition heterogeneities, leading to limitations for cells deeper within the clumps. The accumulation on the walls was reflected in decreasing optical density values after $72 \mathrm{~h}$ (Figure 1B) and a decreasing itaconate productivity (Figure 1A). This is in contrast to the fuz7 mutant, which showed a constant itaconate production rate in the production phase until glucose was depleted. 
Table 3. ITA production parameters of engineered strains of the $U$. maydis MB215 ITA chassis ( $\triangle c y p 3$ $\triangle$ MEL $\triangle$ UA $\Delta$ dgat $\left.\Delta P_{\text {ria } 1}:: P_{\text {etef }}\right)$. \pm values indicate the standard error of the mean $(n=3)$. Symbols refer to Figures 1-3.

\begin{tabular}{|c|c|c|c|c|c|c|}
\hline Conditions. & Symbol & $\begin{array}{l}\text { Strain } \\
\text { Modifica- } \\
\text { tion }\end{array}$ & $\begin{array}{c}\text { ITA } \\
\text { Titer }_{\max } \\
\left(\mathrm{g} \mathrm{L}^{-1}\right)\end{array}$ & $\begin{array}{l}\mathrm{qP}^{\mathrm{a}} \\
\left(\mathrm{g} \mathrm{L}^{-1}\right. \\
\left.\mathrm{h}^{-1}\right)\end{array}$ & $\begin{array}{c}\mathbf{q P}_{\max }{ }^{b} \\
\left(\mathrm{~g} \mathrm{~L}^{-1}\right. \\
\left.\mathbf{h}^{-1}\right)\end{array}$ & $\begin{array}{c}\mathrm{y}_{\mathrm{P} / \mathrm{S}}{ }^{\mathrm{c}} \\
{\left(\mathrm{g}_{\mathrm{ITA}}\right.} \\
\mathrm{g}_{\mathrm{glu}^{-1}}{ }^{-1}\end{array}$ \\
\hline \multirow{7}{*}{$\begin{array}{c}100 \mathrm{mM} \\
\mathrm{MES}^{\prime} \\
50 \mathrm{~g} \mathrm{~L}^{-1} \\
\text { glucose }\end{array}$} & $\Delta$ & control & $19.4 \pm 0.3$ & $0.25 \pm 0.01$ & $0.35 \pm 0.02$ & $0.36 \pm 0.02$ \\
\hline & $\bullet$ & $\Delta f u z 7$ & $24.4 \pm 0.5$ & $0.28 \pm 0.01$ & $0.44 \pm 0.03$ & $0.45 \pm 0.01$ \\
\hline & $\mathbf{\square}$ & $P_{\text {etef }} m t t A \_\mathrm{K} 3$ & $23.5 \pm 0.6$ & $0.20 \pm 0.00$ & $0.46 \pm 0.02$ & $0.53 \pm 0.01$ \\
\hline & $\mathbf{\square}$ & $P_{\text {etef }} m t t A \_\mathrm{K} 8$ & $29.1 \pm 0.1$ & $0.35 \pm 0.01$ & $0.49 \pm 0.03$ & $0.54 \pm 0.01$ \\
\hline & $\square$ & $P_{\text {etef }} m t t A \_\mathrm{K} 9$ & $28.9 \pm 0.3$ & $0.24 \pm 0.00$ & $0.44 \pm 0.01$ & $0.57 \pm 0.01$ \\
\hline & $\square$ & $P_{\text {etef }} m t t A \_\mathrm{K} 10$ & $32.3 \pm 0.8$ & $0.37 \pm 0.00$ & $0.54 \pm 0.01$ & $0.60 \pm 0.02$ \\
\hline & $\mathbf{\square}$ & $P_{\text {etef }} m t t A \_\mathrm{K} 14$ & $29.9 \pm 0.7$ & $0.25 \pm 0.00$ & $0.44 \pm 0.01$ & $0.64 \pm 0.03$ \\
\hline \multirow{6}{*}{$\begin{array}{c}66 \mathrm{~g} \mathrm{~L}^{-1} \\
\mathrm{CaCO}_{3 \prime} \\
100 \mathrm{~g} \mathrm{~L}^{-1} \\
\text { glucose }\end{array}$} & 0 & $\Delta f u z 7$ & $48.8 \pm 1.3$ & $0.42 \pm 0.01$ & $0.70 \pm 0.07$ & $0.47 \pm 0.01$ \\
\hline & $\square$ & $P_{\text {etef }} m t t A \_\mathrm{K} 3$ & $33.8 \pm 0.5$ & $0.29 \pm 0.00$ & $0.43 \pm 0.06$ & $0.58 \pm 0.04$ \\
\hline & $\square$ & $P_{\text {etef }} m t t A \_\mathrm{K} 8$ & $56.5 \pm 1.7$ & $0.48 \pm 0.01$ & $0.74 \pm 0.09$ & $0.51 \pm 0.02$ \\
\hline & $\square$ & $P_{\text {etef }} m t t A \_\mathrm{K} 9$ & $48.1 \pm 2.9$ & $0.41 \pm 0.02$ & $0.52 \pm 0.02$ & $0.56 \pm 0.03$ \\
\hline & $\square$ & $P_{\text {etef }} m t t A \_\mathrm{K} 10$ & $49.0 \pm 3.8$ & $0.42 \pm 0.03$ & $0.64 \pm 0.07$ & $0.44 \pm 0.03$ \\
\hline & $\square$ & $P_{\text {etef }} m t t A \_\mathrm{K} 14$ & $54.4 \pm 0.2$ & $0.46 \pm 0.00$ & $0.82 \pm 0.01$ & $0.57 \pm 0.00$ \\
\hline
\end{tabular}

a Overall itaconate production rate ([glucose] $\left.>5.5 \mathrm{~g} \mathrm{~L}^{-1}\right) .{ }^{\mathrm{b}}$ Maximum itaconate production rate. ${ }^{\mathrm{c}}$ Yield itaconate per consumed glucose.

\subsection{Overexpression of $m t t A$ from A. terreus and Its Impact on Itaconate Production}

The transport of cis-aconitate from the mitochondria to the cytosol is the rate-limiting step in the itaconate production pathway of $U$. maydis $[44,56]$. In the ITA chassis, this bottleneck is addressed through the overexpression of $m t t 1$ caused by the promoter exchange of the itaconate cluster regulator encoded by ria $1[41,56]$. However, the $m t t A$ transporter from $A$. terreus was shown to cause a higher metabolic flux towards itaconate than its $U$. maydis counterpart $M t t 1[10,48]$. Overexpression of both $m t t 1$ and $m t t A$ further enhances itaconate production. Therefore, a $P_{\text {etef }} m t t A$ construct was targeted to the $i p$-locus on the genome of the novel $\Delta f u z 7$ strain.

Targeted integration of CbxR constructs into the ip-locus is not perfect. Often, multicopy integration and/or ectopic insertion into random genomic sites occurs. Therefore, several clones were picked to identify the best itaconate producer. Insertion of at least one $m t t A$ copy was verified by PCR for five clones resulting in the strains listed in Table 3. The strains significantly differed from each other regarding itaconate production, glucose consumption, and growth (Figure 2).

With the exception of $\mathrm{K} 3$, all $m t t A$ transformants outperformed the reference strain with 18-32\% improvements in titer (Figure 2A, Table 3). Clones K3, K9, and K14 did not consume all glucose during $120 \mathrm{~h}$ of cultivation (Figure 2A), which further boosted the yield. All $m t t A$ transformants achieved a higher yield than the reference (Table 3 ), with K14 reaching $0.64 \pm 0.03 \mathrm{~g}_{\mathrm{ITA}} \mathrm{g}_{\mathrm{Glu}}{ }^{-1}$, which is $89 \%$ of the theoretical maximum. Strains K8 and $\mathrm{K} 10$ had the highest rates, which were $25 \%$ and $32 \%$ higher, respectively, compared to the reference. Overexpression of $m t t A$ also had a strong impact on the growth (Figure 2B). While $U$. maydis MB215 $\Delta c y p 3 \Delta \mathrm{MEL} \Delta \mathrm{UA} \Delta d$ dgat $\Delta P_{\text {ria } 1}: P_{\text {etef }} \Delta$ fuz 7 reached $\mathrm{OD}_{600}$ values above 30 , all $m t t A$ transformants remained well below this value. A similar effect was observed in other $m t t A$ overexpressing strains, where growth and glucose consumption were also strongly decreased [48]. The constitutive $\mathrm{P}_{\text {etef }}$ promoter causes expression of $\mathrm{m} t t A$ during the growth phase [58]. It is assumed that this forces cis-aconitate export from the mitochondria to the cytosol, leading to the observed growth defects.

The trends regarding $\mathrm{OD}_{600}$, yield, and rate were similar under screening conditions with a higher substrate concentration and $\mathrm{CaCO}_{3}$ as buffer (Figure 3, Table 3). Much higher titers of up to $56.5 \pm 1.7 \mathrm{~g} \mathrm{~L}^{-1}$ were reached compared to the MES-buffered cultivation due to the higher buffer capacity of $\mathrm{CaCO}_{3}$, higher substrate concentration, and in situ precipitation of calcium itaconate, which alleviates product inhibition. 


\subsection{Correlation between Copy Number of $P_{\text {etef }} m t t A$ and Impact on Itaconate Production}

In order to test whether these differences in production parameters and growth are a result of differences in the copy number of $P_{\text {etef }} m t t A$, the copy number was determined by quantitative PCR. Primer efficiencies and $C_{t}$ values of $m t t A$ and two reference genes, UMAG_02595 and UMAG_03726, were 2.014 for JB-126/JB-127 $\left(\mathrm{R}^{2}=0.999\right), 1.994$ for JB-128/JB-129 $\left(R^{2}=0.999\right)$, and 1.976 for JB-132/JB-133 $\left(R^{2}=1.0\right)$. Ratios between $m t t A$ and each reference gene were calculated independently according to Pfaffl et al. [55] and the resulting mean of both ratios was rounded to an integer value. As positive control, U. maydis MB215 $\triangle$ UMAG_05079 $P_{\text {etef }} m t t A$ was used. This strain was previously proven to be a single-copy $m t t A$ transformant by Southern blot [48], which was confirmed by the qPCR method. For the $m t t A$ transformants, copy numbers between 1 and 4 were determined (Table 4).

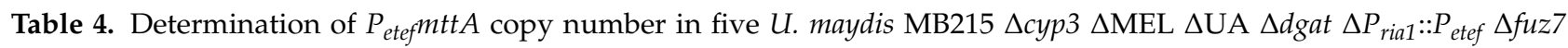
$P_{\text {etef }} m t t A$ transformants by quantitative polymerase chain reaction (PCR). \pm values indicate the standard error of the mean $(n=3)$.

\begin{tabular}{|c|c|c|c|c|c|c|}
\hline U. maydis Strain & $\begin{array}{c}C_{t} \text { Value } \\
\text { UMAG_- }_{0} \\
02595\end{array}$ & $\begin{array}{c}C_{t} \text { Value } \\
\text { UMAG_- } \\
03726\end{array}$ & $\begin{array}{c}C_{\mathrm{t}} \text { Value } \\
m t t A\end{array}$ & $\begin{array}{c}\text { Ratio } m t t A \text { to } \\
\text { UMAG_- } \\
02595\end{array}$ & $\begin{array}{c}\text { Ratio } m t t A \\
\text { to UMAG_ } \\
\quad 03726\end{array}$ & $\begin{array}{c}\text { Rounded } \\
\text { Mean }\end{array}$ \\
\hline wildtype & $27.6 \pm 0.10$ & $27.9 \pm 0.29$ & $35.9 \pm 1.20$ & 0.0 & 0.0 & 0 \\
\hline$\Delta$ UMAG_05079::P $P_{\text {etef }} m t t A$ & $25.7 \pm 0.14$ & $25.8 \pm 0.24$ & $25.7 \pm 0.32$ & 1.0 & 1.0 & 1 \\
\hline$P_{\text {etef }} m t t A \_\mathrm{K} 3$ & $28.3 \pm 0.12$ & $28.4 \pm 0.31$ & $26.7 \pm 0.36$ & 3.2 & 3.1 & 3 \\
\hline$P_{\text {etef }} m t t A \_\mathrm{K} 8$ & $27.8 \pm 0.10$ & $27.9 \pm 0.11$ & $28.5 \pm 0.21$ & 0.7 & 0.6 & 1 \\
\hline$P_{\text {etef }} m t t A \_\mathrm{K} 9$ & $28.2 \pm 0.27$ & $28.5 \pm 0.16$ & $26.4 \pm 0.18$ & 3.7 & 3.9 & 4 \\
\hline$P_{\text {etef }} m t t A \_\mathrm{K} 10$ & $26.8 \pm 0.17$ & $26.6 \pm 0.35$ & $26.6 \pm 0.10$ & 1.2 & 0.9 & 1 \\
\hline$P_{\text {etef }} m t t A \_\mathrm{K} 14$ & $26.6 \pm 0.03$ & $27.0 \pm 0.13$ & $25.2 \pm 0.13$ & 2.8 & 3.3 & 3 \\
\hline
\end{tabular}

Cells of strain $\mathrm{K} 8$ with a single $m t t A$ copy reached the highest $\mathrm{OD}_{600}$ and itaconate production rate (Figure 4). The transformants with higher copy numbers showed lower $\mathrm{OD}_{600}$ and production rates, but significantly higher yields. Transformant K3 represents an outlier, which is most apparent in the direct comparison to K14 having the same copy number of 3. Possibly, one or more copies of the $m t t A$ construct were inserted into a different locus, which may lead to different expression levels or to defects in growth due to gene disruption. Overall, transformant K14 showed the best balance of high yield with minimal reduction in growth and production rates. Therefore, this strain was selected for further characterization.
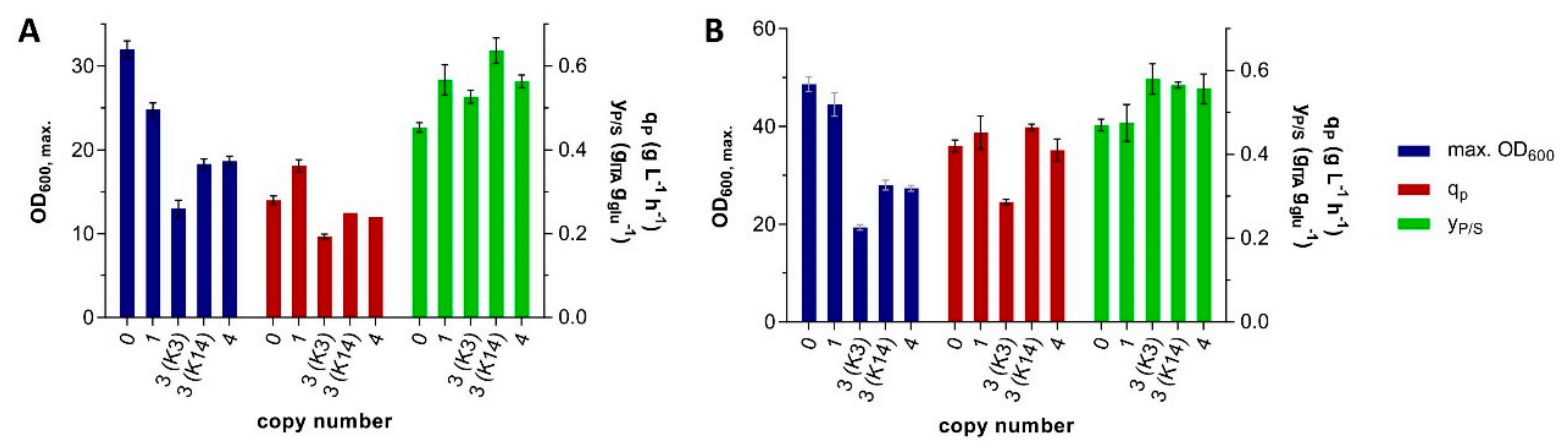

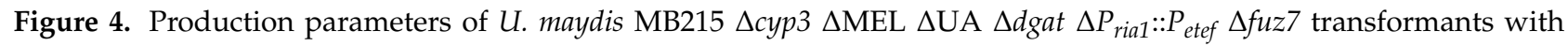
different $m t t A$ copy numbers incubated in MTM with $50 \mathrm{~g} \mathrm{~L}^{-1}$ glucose and $100 \mathrm{mM} \mathrm{MES} \mathrm{(A)} \mathrm{and} \mathrm{with} 100 \mathrm{~g} \mathrm{~L}^{-1}$ glucose and $66 \mathrm{~g} \mathrm{~L}^{-1} \mathrm{CaCO}_{3}(\mathbf{B})$. Error bars indicate the standard error of the mean $(n=3)$. 


\subsection{Evaluation of Itaconate Production with the Novel Engineered Strain K14 in a Bioreactor}

The final consolidated $U$. maydis MB215 $\Delta$ cyp3 $\Delta$ MEL $\Delta \mathrm{UA} \Delta$ dgat $\Delta P_{\text {ria } 1}:: P_{\text {etef }} \Delta$ fuz7 $P_{\text {etef }} m t t A \_\mathrm{K} 14$, henceforth named strain K14 for ease of reference, was deeply engineered to reduce by-product formation, to stabilize the yeast-like morphology, and to alleviate bottlenecks in the itaconate production pathway. This engineering strongly impacted growth, and thus might also affect its catalytic vigor under stress. To assess the performance of the novel engineered strain K14 under more industrially relevant conditions, fed-batch bioreactor experiments were performed.

Previously, in situ crystallization of calcium itaconate was successfully used to achieve very high titers with $U$. maydis MB215 $\Delta c y p 3 \Delta P_{\text {rial }}: P_{\text {etef }} \Delta f u z 7 P_{\text {etef }} m t t A$ [10]. Under similar conditions with $200 \mathrm{~g} \mathrm{~L}^{-1}$ glucose and $4 \mathrm{~g} \mathrm{~L}^{-1} \mathrm{NH}_{4} \mathrm{Cl}$ in the presence of $\mathrm{CaCO}_{3}$, strain $\mathrm{K} 14$ achieved very similar yield, titer and rate of itaconate production (Supplemental Table S2). A titer of $205.6 \pm 1.1 \mathrm{~g} \mathrm{~L}^{-1}$ itaconate was achieved within $481 \mathrm{~h}$ with an overall productivity of $0.43 \pm 0.00 \mathrm{~g} \mathrm{~L}^{-1} \mathrm{~h}^{-1}$ and a yield of $0.32 \pm 0.00 \mathrm{~g}_{\text {ITA }} \mathrm{g}_{\text {glu }}{ }^{-1}$ (Figure 5). Although a very high titer was reached under these conditions due to the alleviation of product inhibition, the yield is relatively low compared to the shaken cultures. After the fermentation, extensive clumping of solids attached to reactor walls and components was discovered, indicating that the shown itaconate production from broth samples during cultivation may be an underestimation. Although the in situ precipitation of itaconate is a very promising strategy, it clearly requires extensive optimization of solids feeding and reactor mixing in order to realize the full potential of the engineered strain.

A

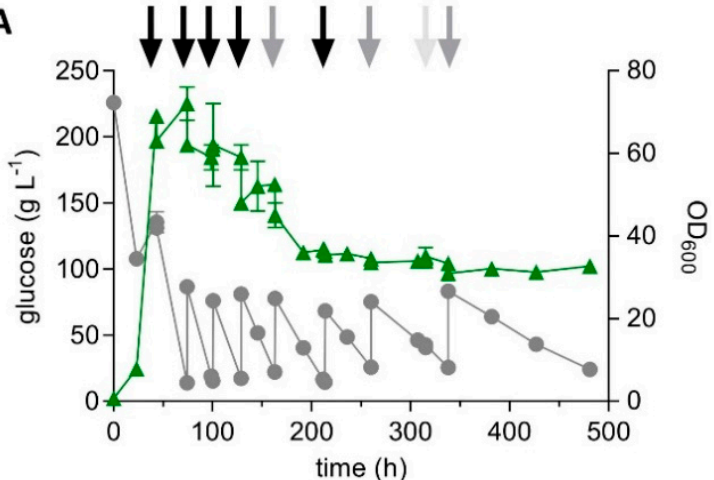

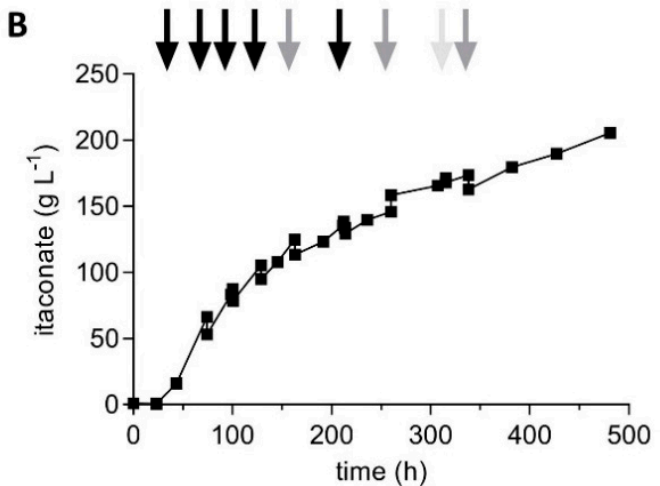

Figure 5. High-density pulsed fed-batch fermentation of $U$. maydis strain K14. (A) concentration of glucose $(\bullet)$ and $\mathrm{OD}_{600}$ values $(\mathbf{\Lambda})$ and (B) concentration of itaconate $(\boldsymbol{\square})$ during fermentation in a bioreactor containing batch medium $\left(200 \mathrm{~g} \mathrm{~L}^{-1}\right.$ glucose, $4 \mathrm{~g} \mathrm{~L}^{-1} \mathrm{NH}_{4} \mathrm{Cl}, \mathrm{CaCO}_{3}$ as buffering agent, $30^{\circ} \mathrm{C}, 1000 \mathrm{rpm}$, top pitched blade impeller, bottom Rushton impeller). Arrows indicate the addition of $80 \mathrm{~g}$ glucose $+50 \mathrm{~g} \mathrm{CaCO}_{3}$ (black arrow), $80 \mathrm{~g}$ glucose (grey arrow), or $50 \mathrm{~g} \mathrm{CaCO}$ (light grey arrow). Error bars indicate the deviation from the mean $(n=2)$.

The intermittent stress imposed by the pulsed feeding strategy likely also negatively affected production. This is especially apparent in $\mathrm{NaOH}$-titrated pulsed fed-batch fermentations, where only $60 \mathrm{~g} \mathrm{~L}^{-1}$ itaconate was produced with a yield of 0.42 gITA $\mathrm{g}_{\mathrm{glu}}{ }^{-1}$ (Supplemental Figure S1). Although this is a considerable improvement compared to a similar fermentation with $U$. maydis MB215 $\Delta$ cyp $\Delta P_{\text {rial } 1: P} P_{\text {etef }} \Delta f u z 7 P_{\text {etef }} m t t A$ [10] (Supplemental Table S2), the achieved yield is still far lower than that obtained in shake flasks. This indicates that the strain modifications, especially the overexpression of $m t t A$, reduced the tolerance of the engineered strains to osmotic stress. Consequently, the novel engineered strain was cultivated in fed-batch fermentations with continuous feed to achieve a lower baseline glucose concentration. High-density fermentations with $4 \mathrm{~g} \mathrm{~L}^{-1} \mathrm{NH}_{4} \mathrm{Cl}$ (Figure 6) as well as low-density fermentations with $0.8 \mathrm{~g} \mathrm{~L}^{-1} \mathrm{NH}_{4} \mathrm{Cl}$ (Figure 7) were performed. A starting glucose concentration of $120 \mathrm{~g} \mathrm{~L}^{-1}$ was allowed to drop to approximately $50 \mathrm{~g} \mathrm{~L}^{-1}$ during growth, at which point a constant feed of 0.75 or $2.8 \mathrm{~g} \mathrm{~h}^{-1}$ was started, for the low and high-density fermentation, respectively. 
A

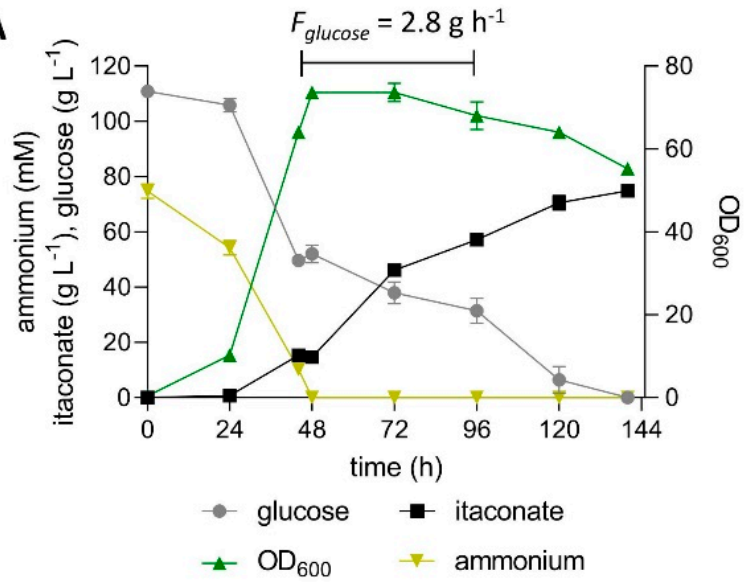

B

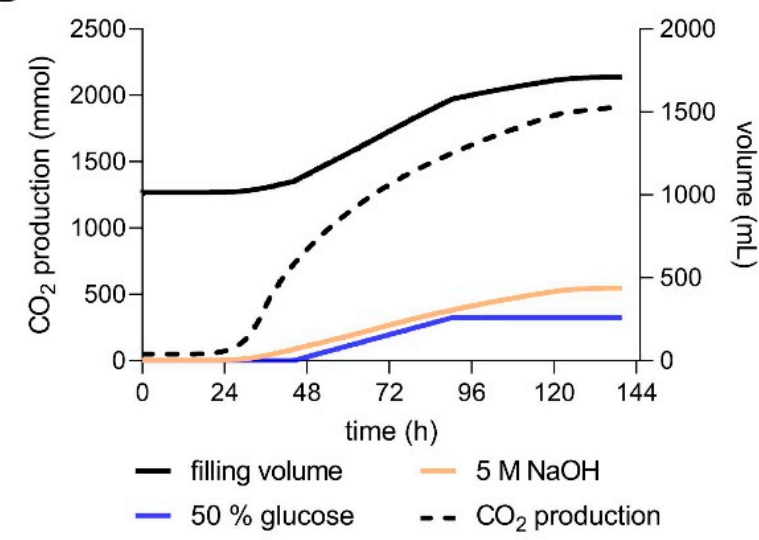

Figure 6. High-density fed-batch fermentation with continuous feed of $U$. maydis strain K14. (A) concentration of glucose, itaconate and ammonium, and $\mathrm{OD}_{600}$ values and (B) filling volume, $\mathrm{CO}_{2}$ production and the added volumes of $5 \mathrm{M} \mathrm{NaOH}$ and $50 \%$ glucose during fermentation in a bioreactor containing batch medium with $120 \mathrm{~g} \mathrm{~L}^{-1}$ glucose and $4 \mathrm{~g} \mathrm{~L}^{-1} \mathrm{NH}_{4} \mathrm{Cl}$. The $\mathrm{pH}$ was kept at 6.5 by automatic titration with $\mathrm{NaOH}$. Cultures were fed with an additional $130 \mathrm{~g}$ glucose at a rate of $2.8 \mathrm{~g} \mathrm{~h}^{-1}$ during the indicated time interval. Error bars indicate the deviation from the mean $(n=2)$.

A

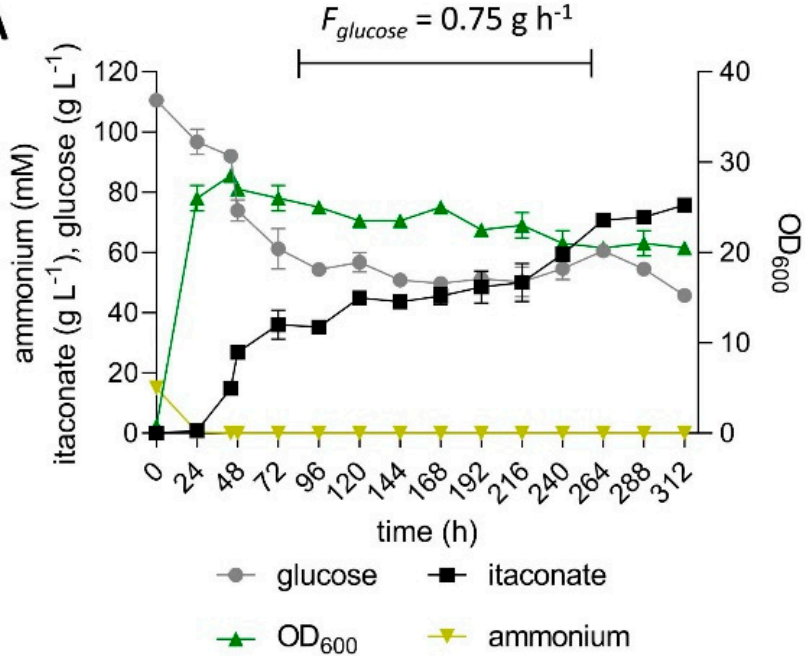

B

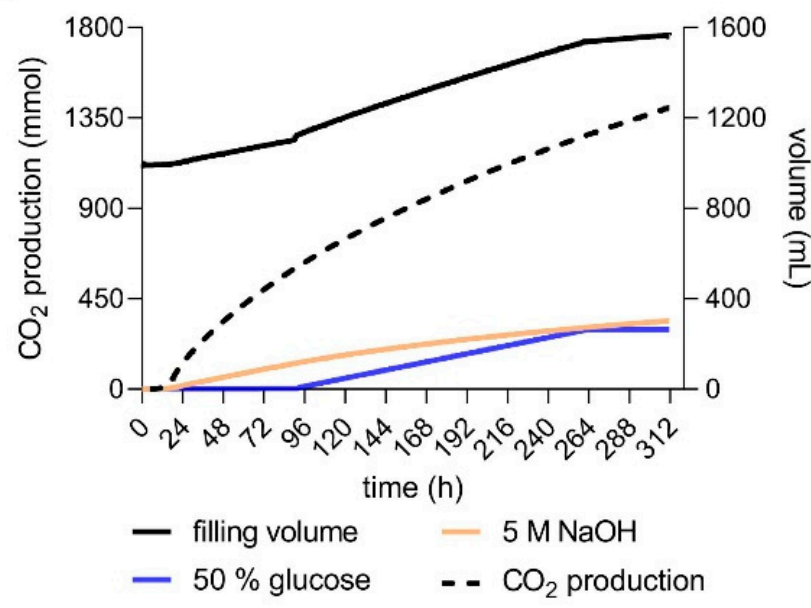

Figure 7. Low-density fed-batch fermentation with continuous feed of $U$. maydis strain K14. (A) concentration of glucose, itaconate and ammonium, and $\mathrm{OD}_{600}$ values and (B) filling volume, $\mathrm{CO}_{2}$ production and the added volumes of $5 \mathrm{M} \mathrm{NaOH}$ and $50 \%$ glucose during fermentation in a bioreactor containing batch medium with $120 \mathrm{~g} \mathrm{~L}^{-1}$ glucose, $0.8 \mathrm{~g} \mathrm{~L}^{-1} \mathrm{NH}_{4} \mathrm{Cl}$. The $\mathrm{pH}$ was kept at 6.5 by automatic titration with $\mathrm{NaOH}$. Cultures were fed with an additional $130 \mathrm{~g}$ glucose at a rate of $0.75 \mathrm{~g} \mathrm{~h}^{-1}$ during the indicated time interval. Error bars indicate the deviation from the mean $(n=2)$.

In the high density fermentation, $74.9 \pm 1.25 \mathrm{~g} \mathrm{~L}^{-1}$ itaconate was produced by the $U$. maydis strain K14 within $140 \mathrm{~h}$ with an overall productivity of $0.53 \pm 0.01 \mathrm{~g} \mathrm{~L}^{-1} \mathrm{~h}^{-1}$ and a yield of $0.54 \pm 0.02 \mathrm{~g}_{\text {ITA }} \mathrm{g}_{\text {glu }}{ }^{-1}$ (Figure 6). The low density fermentation resulted in a similar itaconate titer of $75.7 \pm 1.3 \mathrm{~g} \mathrm{~L}^{-1}$. The five-fold reduction in $\mathrm{NH}_{4} \mathrm{Cl}$ as growth limiting nutrient only resulted in an approximately two-fold reduction of the maximum $\mathrm{OD}_{600}$ value as well as of the overall production rate (Supplemental Table S2). A similar trend was observed previously for both itaconate- and malate-producing strains [44,49]. The lower substrate requirement for biomass formation enabled a higher yield of $0.66 \pm 0.02 \mathrm{~g}_{\text {ITA }}$ $\mathrm{g}_{\mathrm{glu}}{ }^{-1}$ (Figure 7). Compared to the low-density pulsed fed batch (Supplemental Figure S1), the fed batch with continuous feed increased the titer by $27 \%$, the overall productivity by $14 \%$ and the yield by $57 \%$. These results clearly illustrate the benefit of the lower glucose concentration, probably due to a reduced osmotic stress and the absence of osmo shocks 
caused by glucose pulses. A similar trend was observed for an engineered $U$. cynodontis strain, where a constant glucose feed controlled by an in-line glucose sensor significantly increased the production parameters, while lowering the production of erythritol as an osmoprotectant [27]. Erythritol production was not observed in our $U$. maydis cultures, which is in good accordance with previous studies $[28,30]$. However, this species can tolerate over $2.5 \mathrm{osmol} \mathrm{L}^{-1}$ [3] and is known to produce other osmotically active compounds when exposed to such extreme osmotic conditions. Salmerón-Santiago et al. [59] reported that $U$. maydis cells treated with $1 \mathrm{M}$ sorbitol accumulated an increased level of trehalose, probably functioning as an osmoprotectant. The trehalase activity in these cells was increased at the same time, indicating cellular mechanisms for a rapid adaption of the trehalose content. Cervantes-Chávez et al. [60] found that $U$. maydis mutants with a disrupted trehalose biosynthesis pathway were more sensitive to osmotic stress than the wildtype. Assuming that the itaconate produced and the $0.5-1 \mathrm{M}$ glucose pulses had a similar effect, it is reasonable to assume that the $U$. maydis cells were stressed during the pulsed fed-batch fermentations. This stress, combined with the drain of carbon posed by the synthesis of compatible solutes, likely caused the lower itaconate yield.

The yield of $0.66 \pm 0.02 \mathrm{~g}_{\text {ITA }} \mathrm{g}_{\mathrm{glu}}{ }^{-1}$ is the highest yield ever reported for $U$. maydis, and it is also higher than most reported yields achieved with A. terreus [43]. In fact, the low-density fermentation achieved the theoretical maximal yield during the production phase. When disregarding the glucose consumed during the first $24 \mathrm{~h}$ in the growth phase, the yield was $0.72 \pm 0.02 \mathrm{~g}_{\text {ITA }} \mathrm{g}_{\text {glu }}{ }^{-1}$, or $1.00 \pm 0.03 \mathrm{~mol}_{\text {ITA }} \mathrm{mol}_{\text {glu }}{ }^{-1}$.

\section{Conclusions}

This study explored the limits of microbial itaconic acid production with $U$. maydis by combinatorial metabolic and morphological engineering. These modifications, especially the overexpression of $m t t A$, had a major effect on growth of the final strain $U$. maydis K14. This reduction in growth affected its performance in fed-batch reactors, but this effect could be avoided by reducing the glucose concentration with a continuous feeding strategy. Under these conditions, itaconate was produced from glucose at $100 \%$ of the theoretical maximum yield during the production phase in a low-density fermentation. Looking forward, osmotolerance of $U$. maydis may be enhanced by laboratory evolution. Furthermore, production of itaconic acid at low $\mathrm{pH}$ values is also paramount. Although $U$. maydis grows relatively poorly at low $\mathrm{pH}$, the shaken cultures clearly indicate that the $\mathrm{K} 14$ strain is able to produce itaconic acid at $\mathrm{pH}$ levels below 4 . A pH shift between growth and production may therefore enable low- $\mathrm{pH}$ production. Since substrate cost is usually the main price determining factor for commodity products, the high yield achieved in this work will significantly contribute to the establishment of an Ustilago-based industrial itaconate production process, further enabled by the facile, yeast-like growth of this strain.

Supplementary Materials: The following are available online at https:/ / www.mdpi.com/2309-608 X/7/1/20/s1, Figure S1: Low-density pulsed fed-batch fermentation of $U$. maydis strain K14, Table S1: Oligonucleotides used for deletion and overexpression constructs, Table S2: Production parameters of two engineered $U$. maydis MB215 strains in two different types of fed-batch fermentations.

Author Contributions: All authors contributed significantly to the work. J.B., H.H.T. and P.E. contributed equally to this work. Conceptualization, N.W. and L.M.B.; methodology, J.B., H.H.T. and P.E.; validation, J.B., H.H.T. and P.E.; formal analysis, J.B., H.H.T. and P.E; resources, N.W. and L.M.B.; data curation, J.B., H.H.T., P.E., and N.W.; writing-original draft preparation, J.B.; writing-review and editing, P.E. and N.W.; visualization, J.B., H.H.T., P.E. and N.W.; supervision, N.W. and L.M.B.; project administration, N.W. and L.M.B.; funding acquisition, N.W. All authors have read and agreed to the published version of the manuscript.

Funding: The work of J.B. and H.H.T. was funded by the German Federal Ministry of Food and Agriculture (BMEL), through the Specialist agency renewable raw materials e. V. (FNR) as part of the ERA-IB project 'TTRAFFIC' (FKZ 22030515). The work of P.E. was funded by the German Federal Ministry of Education and Research (BMBF) as part of the 'BioökonomieRevier_INNO" 
project "UpRePP" (FKZ 031B0918A). N.W. acknowledges funding from the Bio Based Industries Joint Undertaking under the European Union's Horizon 2020 research and innovation programme under grant agreement No 887711 for the project Glaukos. The lab of L.M.B. was partially funded by the German Research Foundation (DFG) under Germany's Excellence Strategy-Exzellenzcluster 2186 'The Fuel Science Center' (ID:390919832).

Informed Consent Statement: Not applicable.

Data Availability Statement: Data is contained within the article or supplementary material.

Acknowledgments: We thank Kerstin Schipper and Michael Feldbrügge (Institute for Microbiology, Heinrich-Heine University Düsseldorf) for pUMa1523 and pFLPexpC.

Conflicts of Interest: N.W., L.M.B. and H.H.T. are inventors of patent applications on morphological engineering and organic acid production with Ustilago and related fungi. The other authors declare no conflict of interest.

\section{References}

1. Okabe, M.; Lies, D.; Kanamasa, S.; Park, E.Y. Biotechnological production of itaconic acid and its biosynthesis in Aspergillus terreus. Appl. Microbiol. Biotechnol. 2009, 84, 597-606. [CrossRef] [PubMed]

2. Willke, T.; Vorlop, K.D. Biotechnological production of itaconic acid. Appl. Microbiol. Biotechnol. 2001, 56, 289-295. [CrossRef] [PubMed]

3. Klement, T.; Milker, S.; Jäger, G.; Grande, P.M.; Domínguez de María, P.; Büchs, J. Biomass pretreatment affects Ustilago maydis in producing itaconic acid. Microbial. Cell Factories 2012, 11, 43. [CrossRef]

4. Steiger, M.G.; Wierckx, N.; Blank, L.M.; Mattanovich, D.; Sauer, M. Itaconic acid-An emerging building block. In Industrial Biotechnology, Products and Processes; Wiley-VCH Verlag GmbH \& Co. KGaA: Weinheim, Germany, 2017.

5. Werpy, T.; Petersen, G. Top Value Added Chemicals from Biomass: Volume i-Results of Screening for Potential Candidates from Sugars and Synthesis Gas; DOE/GO-102004-1992; TRN: US200427\%\%671 United States 10.2172/15008859 TRN: US200427\%\%671 NREL English; National Renewable Energy Lab.: Golden, CO, USA, 2004.

6. Michelucci, A.; Cordes, T.; Ghelfi, J.; Pailot, A.; Reiling, N.; Goldmann, O.; Binz, T.; Wegner, A.; Tallam, A.; Rausell, A.; et al. Immune-responsive gene 1 protein links metabolism to immunity by catalyzing itaconic acid production. Proc. Natl. Acad. Sci. USA 2013, 110, 7820-7825. [CrossRef] [PubMed]

7. Mills, E.L.; Ryan, D.G.; Prag, H.A.; Dikovskaya, D.; Menon, D.; Zaslona, Z.; Jedrychowski, M.P.; Costa, A.S.H.; Higgins, M.; Hams, E.; et al. Itaconate is an anti-inflammatory metabolite that activates nrf2 via alkylation of keap1. Nature 2018, 556, 113-117. [CrossRef]

8. Olagnier, D.; Farahani, E.; Thyrsted, J.; Blay-Cadanet, J.; Herengt, A.; Idorn, M.; Hait, A.; Hernaez, B.; Knudsen, A.; Iversen, M.B.; et al. Sars-cov2-mediated suppression of nrf2-signaling reveals potent antiviral and anti-inflammatory activity of 4-octyl-itaconate and dimethyl fumarate. Nat. Commun. 2020, 11, 4938. [CrossRef] [PubMed]

9. Klement, T.; Büchs, J. Itaconic acid-A biotechnological process in change. Bioresour. Technol. 2013, 135, 422-431. [CrossRef]

10. Hosseinpour Tehrani, H.; Becker, J.; Bator, I.; Saur, K.; Meyer, S.; Rodrigues Lóia, A.C.; Blank, L.M.; Wierckx, N. Integrated strainand process design enable production of $220 \mathrm{~g} \mathrm{l-1}$ itaconic acid with Ustilago maydis. Biotechnol. Biofuels 2019, 12, 263. [CrossRef]

11. Hevekerl, A.; Kuenz, A.; Vorlop, K.-D. Influence of the ph on the itaconic acid production with Aspergillus terreus. Appl. Microbiol. Biotechnol. 2014, 98, 10005-10012. [CrossRef]

12. Tabuchi, T.; Sugisawa, T.; Ishidori, T.; Nakahara, T.; Sugiyama, J. Itaconic acid fermentation by a yeast belonging to the genus candida. Agric. Biol. Chem. 1981, 45, 475-479. [CrossRef]

13. Levinson, W.E.; Kurtzman, C.P.; Kuo, T.M. Production of itaconic acid by pseudozyma antarctica nrrl y-7808 under nitrogen-limited growth conditions. Enzym. Microb. Technol. 2006, 39, 824-827. [CrossRef]

14. Krull, S.; Lünsmann, M.; Prüße, U.; Kuenz, A. Ustilago rabenhorstiana-An alternative natural itaconic acid producer. Fermentation 2020, 6, 4. [CrossRef]

15. Wierckx, N.; Agrimi, G.; Lübeck, P.S.; Steiger, M.G.; Mira, N.P.; Punt, P.J. Metabolic specialization in itaconic acid production: A tale of two fungi. Curr. Opin. Biotechnol. 2020, 62, 153-159. [CrossRef] [PubMed]

16. Regestein, L.; Klement, T.; Grande, P.; Kreyenschulte, D.; Heyman, B.; Maßmann, T.; Eggert, A.; Sengpiel, R.; Wang, Y.; Wierckx, N.; et al. From beech wood to itaconic acid: Case study on biorefinery process integration. Biotechnol. Biofuels 2018, 11, 279. [CrossRef]

17. Straathof, A.J.J.; Wahl, S.A.; Benjamin, K.R.; Takors, R.; Wierckx, N.; Noorman, H.J. Grand research challenges for sustainable industrial biotechnology. Trends Biotechnol. 2019, 37, 1042-1050. [CrossRef]

18. Kämper, J.; Kahmann, R.; Bölker, M.; Ma, L.-J.; Brefort, T.; Saville, B.J.; Banuett, F.; Kronstad, J.W.; Gold, S.E.; Müller, O.; et al. Insights from the genome of the biotrophic fungal plant pathogen Ustilago maydis. Nature 2006, 444, 97-101. [CrossRef]

19. Kahmann, R.; Steinberg, G.; Basse, C.; Feldbrügge, M.; Kämper, J. Ustilago maydis, the Causative Agent of Corn Smut Disease; Kronstad, J.W., Ed.; Fungal Pathology; Springer: Dordrecht, The Netherlands, 2000; pp. 347-371.

20. Christensen, J.J. Corn smut caused by Ustilago maydis. Monogr. Am. Phytopathol. Soc. 1963, 2. [CrossRef]

21. Kahmann, R.; Kämper, J. Ustilago maydis: How its biology relates to pathogenic development. New Phytol. 2004, 164, 31-42. [CrossRef]

22. Brefort, T.; Doehlemann, G.; Mendoza-Mendoza, A.; Reissmann, S.; Djamei, A.; Kahmann, R. Ustilago maydis as a pathogen. Annu. Rev. Phytopathol. 2009, 47, 423-445. [CrossRef] 
23. Klose, J.; De Sá, M.M.; Kronstad, J.W. Lipid-induced filamentous growth in Ustilago maydis. Mol. Microbiol. 2004, 52, 823-835. [CrossRef]

24. Lovely, C.B.; Aulakh, K.B.; Perlin, M.H. Role of hsl7 in morphology and pathogenicity and its interaction with other signaling components in the plant pathogen Ustilago maydis. Eukaryot. Cell 2011, 10, 869-883. [CrossRef] [PubMed]

25. Lovely, C.B.; Perlin, M.H. Cla4, but not rac1, regulates the filamentous response of Ustilago maydis to low ammonium conditions. Commun. Integr. Biol. 2011, 4, 670-673. [CrossRef] [PubMed]

26. Hosseinpour Tehrani, H.; Tharmasothirajan, A.; Track, E.; Blank, L.M.; Wierckx, N. Engineering the morphology and metabolism of ph tolerant Ustilago cynodontis for efficient itaconic acid production. Metab. Eng. 2019, 54, 293-300. [CrossRef] [PubMed]

27. Hosseinpour Tehrani, H.; Saur, K.; Tharmasothirajan, A.; Blank, L.M.; Wierckx, N. Process engineering of ph tolerant Ustilago cynodontis for efficient itaconic acid production. Microb. Cell Factories 2019, 18, 213. [CrossRef] [PubMed]

28. Guevarra, E.D.; Tabuchi, T. Accumulation of itaconic, 2-hydroxyparaconic, itatartaric, and malic acids by strains of the genus ustilago. Agric. Biol. Chem. 1990, 54, 2353-2358. [CrossRef]

29. Feldbrügge, M.; Kellner, R.; Schipper, K. The biotechnological use and potential of plant pathogenic smut fungi. Appl. Microbiol. Biotechnol. 2013, 97, 3253-3265. [CrossRef]

30. Geiser, E.; Wiebach, V.; Wierckx, N.; Blank, L.M. Prospecting the biodiversity of the fungal family ustilaginaceae for the production of value-added chemicals. Fungal Biol. Biotechnol. 2014, 1, 2. [CrossRef]

31. Bölker, M.; Basse, C.W.; Schirawski, J. Ustilago maydis secondary metabolism-from genomics to biochemistry. Fungal Genet. Biol. FG B 2008, 45 (Suppl. 1), S88-S93.

32. Aguilar, L.R.; Pardo, J.P.; Lomelí, M.M.; Bocardo, O.I.L.; Juárez Oropeza, M.A.; Guerra Sánchez, G. Lipid droplets accumulation and other biochemical changes induced in the fungal pathogen Ustilago maydis under nitrogen-starvation. Arch. Microbiol. 2017, 199, 1195-1209. [CrossRef]

33. Moon, H.-J.; Jeya, M.; Kim, I.-W.; Lee, J.-K. Biotechnological production of erythritol and its applications. Appl. Microbiol. Biotechnol. 2010, 86, 1017-1025. [CrossRef]

34. Zambanini, T.; Tehrani, H.H.; Geiser, E.; Sonntag, C.K.; Buescher, J.M.; Meurer, G.; Wierckx, N.; Blank, L.M. Metabolic engineering of Ustilago trichophora tz1 for improved malic acid production. Metab. Eng. Commun. 2017, 4, 12-21. [CrossRef] [PubMed]

35. Müller, M.J.; Stachurski, S.; Stoffels, P.; Schipper, K.; Feldbrügge, M.; Büchs, J. Online evaluation of the metabolic activity of Ustilago maydis on (poly) galacturonic acid. J. Biol. Eng. 2018, 12, 1-17. [CrossRef] [PubMed]

36. Schlembach, I.; Tehrani, H.; Blank, L.M.; Büchs, J.; Wierckx, N.; Regestein, L.; Rosenbaum, M. Consolidated bioprocessing of cellulose to itaconic acid by a co-culture of Trichoderma reesei and Ustilago maydis. Biotechnol. Biofuels 2020, 13, 1-18. [CrossRef] [PubMed]

37. Geiser, E.; Reindl, M.; Blank, L.M.; Feldbrügge, M.; Wierckx, N.; Schipper, K. Activating intrinsic carbohydrate-active enzymes of the smut fungus Ustilago maydis for the degradation of plant cell wall components. Appl. Environ. Microbiol. 2016, 82, 5174-5185. [CrossRef]

38. Stoffels, P.; Müller, M.J.; Stachurski, S.; Terfrüchte, M.; Schröder, S.; Ihling, N.; Wierckx, N.; Feldbrügge, M.; Schipper, K.; Büchs, J. Complementing the intrinsic repertoire of Ustilago maydis for degradation of the pectin backbone polygalacturonic acid. $J$. Biotechnol. 2020, 307, 148-163. [CrossRef]

39. Maassen, N.; Panakova, M.; Wierckx, N.; Geiser, E.; Zimmermann, M.; Bölker, M.; Klinner, U.; Blank, L.M. Influence of carbon and nitrogen concentration on itaconic acid production by the smut fungus Ustilago maydis. Eng. Life Sci. 2014, 14, 129-134. [CrossRef]

40. Olicón-Hernández, D.R.; Araiza-Villanueva, M.G.; Pardo, J.P.; Aranda, E.; Guerra-Sánchez, G. New insights of Ustilago maydis as yeast model for genetic and biotechnological research: A review. Curr. Microbiol. 2019, 76, 1-10. [CrossRef]

41. Becker, J.; Hosseinpour Tehrani, H.; Gauert, M.; Mampel, J.; Blank, L.M.; Wierckx, N. An Ustilago maydis chassis for itaconic acid production without by-products. Microb. Biotechnol. 2020, 13, 350-362. [CrossRef]

42. Karaffa, L.; Kubicek, C.P. Citric acid and itaconic acid accumulation: Variations of the same story? Appl. Microbiol. Biotechnol. 2019, 103, 2889-2902. [CrossRef]

43. Kuenz, A.; Krull, S. Biotechnological production of itaconic acid-Things you have to know. Appl. Microbiol. Biotechnol. 2018, 102, 3901-3914. [CrossRef]

44. Geiser, E.; Przybilla, S.K.; Engel, M.; Kleineberg, W.; Büttner, L.; Sarikaya, E.; Hartog, T.D.; Klankermayer, J.; Leitner, W.; Bölker, M.; et al. Genetic and biochemical insights into the itaconate pathway of Ustilago maydis enable enhanced production. Metab. Eng. 2016, 38, 427-435. [CrossRef]

45. Zambanini, T.; Hosseinpour Tehrani, H.; Geiser, E.; Merker, D.; Schleese, S.; Krabbe, J.; Buescher, J.M.; Meurer, G.; Wierckx, N.; Blank, L.M. Efficient itaconic acid production from glycerol with Ustilago vetiveriae tz1. Biotechnol. Biofuels 2017, 10, 131. [CrossRef]

46. Duetz, W.A.; Rüedi, L.; Hermann, R.; O'Connor, K.; Büchs, J.; Witholt, B. Methods for intense aeration, growth, storage, and replication of bacterial strains in microtiter plates. Appl. Environ. Microbiol. 2000, 66, 2641-2646. [CrossRef] [PubMed]

47. Hewald, S.; Josephs, K.; Bölker, M. Genetic analysis of biosurfactant production in Ustilago maydis. Appl. Environ. Microbiol. 2005, 71, 3033-3040. [CrossRef] [PubMed]

48. Hosseinpour Tehrani, H.; Geiser, E.; Engel, M.; Hartmann, S.K.; Hossain, A.H.; Punt, P.J.; Blank, L.M.; Wierckx, N. The interplay between transport and metabolism in fungal itaconic acid production. Fungal Genet. Biol. FG B 2019, 125, 45-52. [CrossRef]

49. Zambanini, T.; Sarikaya, E.; Kleineberg, W.; Buescher, J.M.; Meurer, G.; Wierckx, N.; Blank, L.M. Efficient malic acid production from glycerol with Ustilago trichophora tz1. Biotechnol. Biofuels 2016, 9, 67. [CrossRef] [PubMed]

50. Gibson, D.G.; Young, L.; Chuang, R.Y.; Venter, J.C.; Hutchison, C.A., 3rd; Smith, H.O. Enzymatic assembly of DNA molecules up to several hundred kilobases. Nat. Methods 2009, 6, 343-345. [CrossRef] [PubMed]

51. Sambrook, J.; Russell, D.W. Preparation and transformation of competent e. coli using calcium chloride. CSH Protoc. 2006, 2006. [CrossRef] 
52. Brachmann, A.; König, J.; Julius, C.; Feldbrügge, M. A reverse genetic approach for generating gene replacement mutants in Ustilago maydis. Mol. Genet. Genom. 2004, 272, 216-226. [CrossRef] [PubMed]

53. Hoffman, C.S.; Winston, F. A ten-minute DNA preparation from yeast efficiently releases autonomous plasmids for transformaion of Escherichia coli. Gene 1987, 57, 267-272. [CrossRef]

54. Khrunyk, Y.; Münch, K.; Schipper, K.; Lupas, A.N.; Kahmann, R. The use of flp-mediated recombination for the functional analysis of an effector gene family in the biotrophic smut fungus Ustilago maydis. New Phytol. 2010, 187, 957-968. [CrossRef] [PubMed]

55. Pfaffl, M.W. A new mathematical model for relative quantification in real-time rt-pcr. Nucleic Acids Res. 2001, 29, e45. [CrossRef] [PubMed]

56. Geiser, E.; Przybilla, S.K.; Friedrich, A.; Buckel, W.; Wierckx, N.; Blank, L.M.; Bölker, M. Ustilago maydis produces itaconic acid via the unusual intermediate trans-aconitate. Microb. Biotechnol. 2016, 9, 116-126. [CrossRef] [PubMed]

57. Geiser, E.; Hosseinpour Tehrani, H.; Meyer, S.; Blank, L.M.; Wierckx, N. Evolutionary freedom in the regulation of the conserved itaconate cluster by ria1 in related ustilaginaceae. Fungal Biol. Biotechnol. 2018, 5, 14. [CrossRef]

58. Zambanini, T.; Hartmann, S.K.; Schmitz, L.M.; Büttner, L.; Hosseinpour Tehrani, H.; Geiser, E.; Beudels, M.; Venc, D.; Wandrey, G.; Büchs, J.; et al. Promoters from the itaconate cluster of Ustilago maydis are induced by nitrogen depletion. Fungal Biol. Biotechnol. 2017, 4, 11. [CrossRef]

59. Salmerón-Santiago, K.G.; Pardo, J.P.; Flores-Herrera, O.; Mendoza-Hernández, G.; Miranda-Arango, M.; Guerra-Sánchez, G. Response to osmotic stress and temperature of the fungus Ustilago maydis. Arch. Microbiol. 2011, 193, 701-709. [CrossRef]

60. Cervantes-Chávez, J.A.; Valdés-Santiago, L.; Bakkeren, G.; Hurtado-Santiago, E.; León-Ramírez, C.G.; Esquivel-Naranjo, E.U.; Landeros-Jaime, F.; Rodríguez-Aza, Y.; Ruiz-Herrera, J. Trehalose is required for stress resistance and virulence of the basidiomycota plant pathogen Ustilago maydis. Microbiology 2016, 162, 1009-1022. [CrossRef] 